This work is licensed under a Creative Commons Attribution 4.0 International License.

Ovaj rad dostupan je za upotrebu pod licencom Creative Commons Imenovanje 4.0 međunarodna.

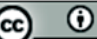

Gregory S. THELLMAN

UDK 27-247.4

Visoko evanđeosko teološko učilište

$27-277$

Cvjetkova 32

HR - 31000 Osijek

DOI: https://doi.org/10.29162/ANAFORA.v6i1.2

greg.thellman@evtos.hr

Izvorni znanstveni članak

Original Research Article

Primljeno 16. veljače 2019.

Received: 16 February 2019

Prihvaćeno 12. ožujka 2019.

Accepted: 12 March 2019

\title{
THE NARRATIVE-THEOLOGICAL FUNCTION OF MATTHEW'S BAPTISM COMMAND (MATTHEW 28:19b)
}

\begin{abstract}
The triadic name given in the baptism command of Matthew 28:19b has often been considered awkward in its context and perhaps anachronistic in light of later Christian Trinitarian doctrine. This article argues that Matthew 28:19b is rather a fitting climactic conclusion to a narrative-theological motif throughout Matthew's Gospel where triadic or at least dyadic language is employed within revelatory contexts that affirm Jesus' divine sonship and messianic mission: either in small apocalypses or within apocalyptic discourse. This argument finds its crux in the baptism of Jesus itself (3:13-17) which is presented as an apocalypse in which the heavenly fatherly voice reveals the identity of the Son and anoints him with his Spirit, with the stated goal of "fulfilling all righteousness." The revelation is presented by Matthew so that it is directed to the public within the narrative and implicitly to the reader disciple. The baptism revelation is then closely associated both with the lengthy citation of Isaiah 42:1-4 in Matthew 12:18-21, another triadic text, and with the visionary transfiguration account (17:1-8). Other passages are analyzed in order to trace the pattern throughout the Gospel. In the resurrection narrative (28:1-20) it is demon-
\end{abstract}


strated that the resurrected Jesus is portrayed as a now heavenly, yet still embodied, revealer who is worshipped such that the Great Commission passage (28:16-20) is presented as a divine revelation. Within this "ultimate apocalypse" the risen Jesus commands his followers to make disciples of the nations by teaching and baptizing in the triadic name. The baptism command, in light of the triadic motif throughout the Gospel has the rhetorical effect of inviting Matthew's reader-listener disciples to identify with Jesus in his own triadic baptism such that they too have an affirmed filial relationship with God and receive the anointing of the Holy Spirit to continue and extend Jesus' messianic mission into the world under his universal authority and with his promised presence.

Key Words: Jesus, Gospel of Matthew, Father, Holy Spirit, baptism, revelation, apocalyptic, Trinity

\section{Introduction}

Critical scholarship's response to Jesus' command to make disciples by baptizing in the triadic name of the Father, Son and Holy Spirit in Matthew 28:19b often begins with a caveat that the triadic expression should not be taken in a later "trinitarian" sense. In addition, it is often asserted that literarily the saying seems foreign to its narrative context (France 2007: 116). One reviewer finds the expression so surprising that he likens it to a "bolt from the blue" (Viviano 1984: 177). From a historical perspective, commentators are skeptical that such a saying could have come from Jesus. ${ }^{1}$ These initial responses reflect three crucial, but interrelated questions about this expression. ${ }^{2}$ First is the question of origin, that is, is the expression i) traditional-in which case, does the expression represent at least the ipsissima vox Jesu that has been passed down to the evangelist? ii) a Matthean redaction of an existing tradition, iii) a fully Matthean composition or iv) an altogether later interpolation, based on an existing church baptismal practice? ${ }^{3}$ Second, how does the expression fit (or not fit) within the narrative context of the pericope (Matt 28:16-20) and the Gospel narrative as a whole and what is therefore its rhetorical function for Matthew's reader-listener disciples? ${ }^{4}$ Finally, given the doctrine of the Trinity, to what extent does Mat-

1 The argument is that if Jesus had in fact instructed his disciples in this manner, it is difficult to explain why it is not attested as such elsewhere in the NT. However, it is present in the Didache $(7.1 ; 7: 3)$.

2 The questions are interrelated because each question's answer impacts the others.

3 For a full discussion of the options see Schaberg (1982: 29-42). 
thew's expression already reflect a Trinitarian concept or at least anticipate or contribute to its development?

The first and third questions - the historical and doctrinal- have largely driven the discussion in the past. This has resulted within historical critical studies in a rather atomistic approach to the expression. ${ }^{6}$ But if the saying itself seems to modern interpreters as anachronistic in its Matthean context, could it not well be that the appearance of anachronism is due to the text's overfamiliarity as an isolated text in its subsequent doctrinal and liturgical application? What is necessary then, is to attempt to "defamiliarize" the text and to appeal to the second question above: how well does the expression fit within the larger narrative context of the Gospel?? To be certain, taking a narrative critical approach

I make no claims about the historical identity of the author. Nor do I make any distinction between the real author, implied author and narrator. As Kingsbury (1988: 31-33) shows, the Matthean narrator is reliable and thus equivalent to the implied author. In addition, because the Gospel is formally anonymous and makes no internal historical claims for authorship, I agree with Powell (2009: 63-64) that "almost all of our suppositions concerning the author of Matthew's Gospel are in fact derived from the work itself; thus, the 'implied author of Matthew's Gospel' . . . offers about as close a picture of the real author of that book as we are likely to obtain, " so that the "intention of the implied author' discernible through narrative criticism may be taken as an index of the intention of the actual author." Similarly, by "Matthew's reader/listener disciples," I have in mind the implied or ideal reader as "an index" of the intended real readers of Matthew's present and future. In my view the Gospel of Matthew presents itself as a narrative intended for all present (at the time of writing) and potential disciples of Jesus. Again, the Gospel makes no inherent claims to provenance or intended audience, and all scholarly attempts at a description of a supposed Matthean community or communities are at best uncertain and sometimes quite conjectural. Therefore, to extend Powell's above insights a step further, the implied or ideal reader can be an approximate representative of the real author's intended readers, who are in effect potentially ideal disciples.

$5 \quad$ Schaberg (1982: 6-7), reasons that to be "trinitarian" in at least a basic way would require that all three figures would be conceived of as being in unity, with an essential equality (though with an order of subordination), and that the Spirit is described in personal terms.

6 The fullest treatment on the subject is that of Schaberg (1982). While Schaberg provides a helpful overview of the issues and agrees that the triadic name must be interpreted within its context, she views the pericope as a Matthean appropriation of a proposed existing midrash based on Daniel 7 and the triadic figures of the Ancient of Days, Son of Man and angels. This link, however, is, as Luz (2005: 632) comments, somewhat "speculative" and goes well outside available textual evidence.

7 The emergence of narrative criticism over the past forty years in New Testament scholarship is well known, and while in its beginnings the method may have been practiced in more of a pure sense, decidedly apart from the historical concerns of the traditional historical-critical method, thankfully the two approaches have grown closer together, with historical critics making use of narrative methods and narrative critics taking a more comprehensive approach (Brown 2013: 619-24; Rhoads 1999: 269). A critical approach that values both the narrative aims of the whole composition while maintaining historical concerns is sometimes referred to as "composition criticism." That is the approach of the present paper. 
to the Matthean conclusion is not new. Most notably, Kingsbury (1974: 573-84) argued that the entire Great Commission passage (Matt 28:16-20) was a Matthean composition based on Matthew's "Son of God" Christology. Kingsbury's argument draws attention to the literary consistency of the passage in its current form with themes from the remainder of the Gospel. However, I suggest a more tightly woven narrative-theological motif within Matthew's narrative that anticipates and illuminates the rhetorical force of the baptism command within the Gospel's concluding passage. ${ }^{8}$ But, as is the case with Matthew 28:19b itself, the great familiarity with these texts might prohibit observation of certain qualities that might shed greater light on their interconnectedness. I suggest that one of those qualities is their shared revelatory, or apocalyptic, character, which Matthew applies rhetorically to draw the reader-listener into the narrative as a recipient of revelation.

The proposal of this paper is that Matthew's triadic statement in $28: 19 \mathrm{~b}$ provides a rather fitting climax and conclusion to a narrative-theological thread that runs throughout the Gospel incorporating two elements: 1) narration of or reference to an apocalypse (divine revelation) - or, the implementation of apocalyptic discourse $-{ }^{9}$ concerning Jesus' messianic and divine identity, and 2) affirmation or authorization by God the Father of Jesus the Son's eschatological salvific mission to produce a people of righteousness through the empowerment and leading of God's (Holy) Spirit.

In the following section (2), I will trace the development of this pattern in key texts in Matthew's Gospel. While these elements converge first in the angelic revelation of divine conception (1:18-23), they do so most explicitly and crucially in the event of Jesus' baptism itself (3:11-17), followed by teaching in the first two of Jesus' discourses regarding the Father (5:16-7:21) and Spirit (10:20). In 11:25-27, Jesus elucidates the reciprocal revelatory roles of Father and Son, preparing the reader for further triadic discourse in chapter 12 which recalls and confirms the revelation at the baptism and establishes Matthew's pneuma-

8 In addition, I do not think it necessary to argue that the passage as a whole is a "Matthean composition." In my view, the pre-history of the passage cannot be detected with great certainty, and in the end, whether reworked tradition or not, the text is Matthew's.

$9 \quad$ According to Carey (1999: 10), "apocalyptic discourse refers to the constellation of apocalyptic topics as they function in larger early Jewish and Christian literary and social contexts. Thus, apocalyptic discourse should be treated as a flexible set of resources that early Jews and Christians could employ for a variety of persuasive tasks." 
tological outlook. In addition, the Petrine confession (16:13-17) and the transfiguration (17:1-8) contribute to the pattern of divine Fatherly affirmations of Jesus' identity and mission while the release of "the spirit" in Matthew 27:50 after the cry of dereliction implies the reversal of the baptismal revelation. Each of these passages link "Jesus" or "son" with "Father" and sometimes "Spirit," (i.e. triadic or dyadic) and narrate or refer to revelation that affirms or authorizes the filial identity of Jesus and his Spirit empowered mission, often explicating or anticipating the inclusion of Jesus' disciples in a derivative filial identity and in the same messianic mission.

I will then show in section three that the triadic baptism command functions within Matthew's conclusion (Matt 28:16-20) to appropriately conclude this distinctive triadic narrative-theological pattern. The resurrected Jesus there takes on the role of heavenly divine revealer himself and is positioned alongside the Father and the Holy Spirit as such. The triadic baptism command thus serves to draw future reader-listener disciples within the narrative world as hearers of Jesus' revelatory command that they may too be recipients of the same Spirit empowered and fatherly affirmed messianic mission inaugurated at Jesus' own baptism. In this way the rhetorical function of the command is to unify disciples in the revealed and affirmed messianic identity and mission. Finally, I will reflect briefly on the implications of these conclusions with regard to the origins of the expression and its nature as a "Trinitarian" concept.

\section{The Revelatory Triadic Motif in Matthew's Narrative}

Father (God)-Son (Jesus)-Spirit (Holy Spirit or Spirit of God) language abounds in Matthew's Gospel. While the relationships between these vital "characters" in Matthew's story are various, their appearances, often together, are multiple. Of course, the Gospel is narrative about Jesus, who is referred to in various ways as "Son" ("Son of man", "Son of God", "the Son"), and although God is at times implicit in the text as a character-through angelic messengers for example, or by use of the divine passive-he does nevertheless explicitly "appear" in a number of texts, both narrations and citations, in conjunction with or in relation to Jesus. ${ }^{10}$ To a lesser extent, the "Holy Spirit" or "Spirit" likewise appears in conjunction with Jesus, and also with God (the Father) as well, al-

10 Of course, God as Father, as will be shown below, is an explicit character within the cited speech of Jesus. 
though the Spirit's explicit presence seems to fade as the narrative progresses. I will address this feature below, as well as the question of whether the Spirit can indeed be considered a "character" in the First Gospel, and perhaps consequently a personal agent.

I now turn to the most relevant passages in which Jesus, sometimes explicitly named as "Son" is interwoven with the revelatory actions or words of the Father, or God, and/or (the) Spirit. In each case, the narrative is characterized by apocalyptic discourse and an affirmation of the Messianic mission of Jesus.

\subsection{The Revelation of the Holy Spirit Conception of the Messiah (Matthew 1:18-23)}

Matthew's account of the "genesis" ( $\gamma \varepsilon \dot{v \varepsilon \sigma ı \varsigma) ~ o f ~ J e s u s ~ t h e ~ M e s s i a h ~(1: 18 ; ~ c f . ~}$ 1:1) begins with the narrator's statement that Mary was found to be pregnant $\dot{\varepsilon} \kappa \pi v \varepsilon \dot{u} \mu a \tau o c$ áyiov. The Spirit conception is then confirmed through the narrated revelation of the angel of the Lord, ä $\gamma \gamma \varepsilon \lambda$ os kupiov, to Joseph in a dream

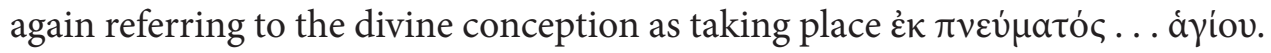
The construction $\dot{\varepsilon} \kappa \pi v \varepsilon v \mu a \tau o \zeta$ is unusual in contemporary Jewish literature. However, the verb $\gamma \varepsilon v v \alpha \dot{\omega} \omega$ followed by $\dot{\varepsilon} \kappa$ is a fairly standard way to designate most typically the mother of a begotten child, ${ }^{11}$ though it can be used to designate both parents, ${ }^{12}$ or more rarely the father specifically. ${ }^{13}$ The $\gamma \varepsilon v v a \omega+\dot{\varepsilon} \kappa$ construction appears then to most frequently designate parenthood and consequently personal agency in birth. ${ }^{14}$ Some commentators, however, caution against a parental understanding of the Spirit's role warning that the language is not meant to describe paternity but rather the power of God to bring about this unique virginal birth. ${ }^{15}$ As Garland (2001:22) surmises, "it makes clear that the salvation that is offered in Jesus does not come from any human potentiality." However correct this warning, it is not therefore necessary to describe the action of the Holy Spirit here as an impersonal manifestation of divine power. ${ }^{16}$

11 It is found in the preceeding genealogy on four occasions $(1: 5-6,16)$ in each case used to identify the mother of the aforementioned offspring while the father is the active subject of $\gamma \varepsilon v v \alpha \dot{\alpha} \omega$. In the final case, Jesus, the "one called Christ" is said to to have been born (passive of $\gamma \varepsilon v v a \omega$ ) from

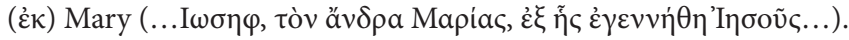

12 Philo, Cher 53; Spec 1.313; 4.182.

$13 \quad$ LXX 2 Kgs 20:18; T. Sim. 2:2; T. Jos. 19:3

14 The Gospel of John (3:5-8) uses the construction to describe spiritual rebirth.

15 Nearly all agree that the virginal conception is assumed and not argued by Matthew.

16 For example, Davies and Allison (1988: 1:208), emphasize that the lack of the article here (in contrast to 28:19) shows the Spirit not to be a person, but rather the "OT concept . . . of divine 
The appearance of the Spirit in this text should be seen in light of the Spirit's role in creation (Gen 1:2; Ps 33:6) and expected role as the divine initiator of eschatological new creation in conjunction with the advent of the Messiah (Barrett 1947: 17-24; France 2007: 50). ${ }^{17}$ The eschatological-new creation role of the Spirit in the life and ministry of Jesus comes into greater focus as the narrative develops. ${ }^{18}$ Matthew's language here appears to be quite purposefully original. ${ }^{19}$ I will return to the question of the Spirit as a character or personal agent in the narrative below.

God however is also apparent in this text. The appellation ä $\gamma \gamma \varepsilon \lambda$ oৎ kvpiov, angel of the Lord, would remind readers of the unique agent of YHWH (LXX кúpıs) in the OT whose identity is often ambiguously close to the identity of YHWH himself. ${ }^{20}$ Though not typically viewed as such, this passage-as well as the remaining angelic revelations in the infancy narrative (1:18-2:23) - conform to the now standard scholarly definition of 'apocalypse' as a mediated revelation in a narrative framework of transcendent and eschatological realities (Collins 1979). ${ }^{21}$ As an angel of YHWH, this messenger clearly discloses a message from

power and energy." They also point out that there is no "male principle" involved because of the neuter Greek noun $\pi v \varepsilon v \dot{\mu} \mu$ and the feminine Hebrew noun חור. However, the OT conception of the Spirit of God is not evidently non-personal (Thiselton 2013: 3-21).

17 See for example Ezekiel 36:26; 37:1-14; Isaiah 11:2; 42:1; 44:3.

18 Even in Matthew 1, however, a new creation allusion may be present in the two-time use of

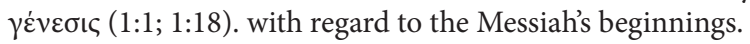

19 Aus (2004: 31-32), argues that Matthew is drawing directly on the Jewish tradition regarding Miriam, Moses' sister and her Holy Spirit inspired dream as reported in $L A B$ 9:10. While I would agree that there are typological congruences, Matthew's syntactical construction does not match that of $L A B$ 9:10. Aus concedes (fn 146) that Matthew's "usage ... is new." Some scholars have drawn on pagan parallels of women made pregnant by a divine spirit (Plutarch, Num 4.4). However, it is difficult to conceive that a writer like Matthew had this in mind. It is better understood as a miraculous birth in climactic continuity with examples from the OT scriptures (Sarah, Hannah, etc.) and perhaps Jewish tradition (Moses' birth), only now the divine power was such that no human male was needed for this act of new creation.

20 In second temple literature, "angel of the Lord" does not typically have the same connotations as in the OT literature, as angels were conceived of as more personal entities. But it is also possible that, in light of the developments in angelology in the second temple period, "angel of the Lord" infers the angels of the presence often found in apocalyptic literature. For angels in Matthew see Bendoraitis (2017: 31-52).

21 Collins' (1979: 9) definition of apocalypse is "a genre of revelatory literature with a narrative framework, in which a revelation is mediated by an otherworldly being to a human recipient, disclosing transcendent reality which is both temporal, insofar as it envisages eschatological salvation, and spatial insofar as it involves another, supernatural world." While Matthew as a whole does not fit this paradigm, these passages function as smaller 'apocalypses' with the Gospel narrative. 
God himself to Joseph concerning the conception, naming and salvific purpose of the child.

But Matthew as narrator provides further explanation of this revelation as the fulfillment of a prophecy of Isaiah: "Behold, the virgin shall conceive and

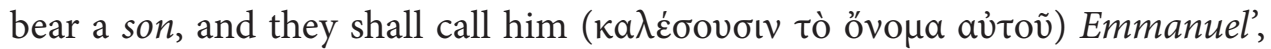
which means God with us." Now, the Spirit-conceived Son is further identified by Matthew as a human in whom God is fully present. The deliverance for Israel and the house of David in Isaiah 7:14 is now filled out to the full in the climactic deliverance from sins to be enacted by Jesus in whom, Matthew tells readers, God is present "with us."

The matrix of relationships between the son of Mary, the Holy Spirit and God (or YHWH through his angel) is brought together via divine revelation mediated by the angel and Matthew's own explanatory narration. Together they disclose the transcendent reality of the fullness of divine presence in the son (Emmanuel), and his eschatological salvific mission to Israel (Jesus).

\subsection{The Revelation to the Spirit-Anointed Son: The First Fatherly Affirmation} (Matthew 3:13-4:1)

The Father-Son-Spirit imagery is next found in the account of Jesus' baptism. Matthew's unique shaping of this synoptic tradition is significant. First, Matthew alone among the Gospels includes dialogue between John and Jesus about the necessity for Jesus' baptism. Jesus' assertion that he should be baptized to "fulfill all righteousness" is best understood as the goal of Jesus' complete messianic mission in light of OT texts that look forward to a righteous eschatological covenant community in the messianic age, (see especially Isa 60:21; 61:3; Jer 31:34; Ezek 37:24,27). Jesus thus submits to what is otherwise a baptism of repentance, in order to fully identify with his people in their sinful state (or spiritual exile), foreshadowing the cross and resurrection. It is therefore an essential event for the carrying out and implementation of the messianic mission, the end goal of which is restoration (or end of exile, new Exodus) and the eschatological covenant righteousness (Matt 13:43) of God's people (Wright 1996: 537-39).

It should not be overlooked however that the baptism account is also a narrated revelation-the open heavens (Ezek 1:1), the descent of the Spirit and the divine voice all contribute to a thoroughly apocalyptic scene. Capes calls the baptism "one example of early Christian apocalypses" (Capes 1999: 40; cf. 
Mathewson 2011: 89-108). Although this designation holds true in each of the synoptic accounts, Matthew's account intensifies the apocalyptic nature of the episode in multiple ways. First, Matthew introduces successive revelatory events with íovi (look!), an often overlooked particle that at the least serves to exhort readers and listeners to pay special attention, but which by the first century CE represents a narrative device for introducing apocalyptic discourse. ${ }^{22}$ Second, Matthew differs from both Mark and Luke by quoting the voice in the third person: "this is my beloved son, with whom I am well pleased" (as opposed to "you are my son"). This shift of perspective serves, as many interpreters see it, to conflate the royal son typology of Psalm 2:7 with the servant typology of Isa 42:1, and as such more tightly linking the baptism event with Matthew's lengthy quotation of this passage in chapter 12 (18-21), and with the transfiguration (17:1-4). In addition, though, the shift in person makes the statement a public revelatory proclamation within the narrative, which also serves rhetorically to make the reader-listener disciple a direct recipient of the revelation. Finally, the apocalyptic scene is further intensified by Matthew's arrangement of the temptation narrative in which Jesus is led by the Spirit, immediately following the baptism. Only Matthew immediately follows the baptism apocalypse with the complete visionary scene of the temptation. ${ }^{23}$

As a narrated revelation, heavenly secrets are unveiled at Jesus' baptism. ${ }^{24}$ The descent of the Spirit likely reiterates the new creation imagery at the conception, but now more directly associated with the OT eschatological promise of a Spirit endowed Messiah to restore Israel. Whereas at his conception Jesus was born

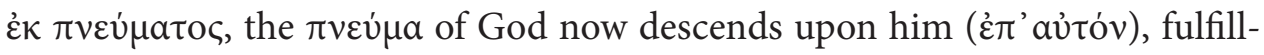

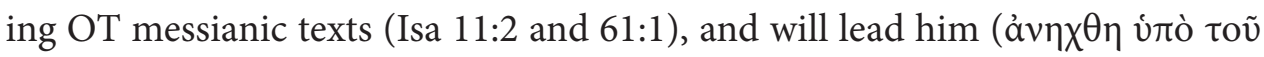
$\pi v \varepsilon \dot{u} \mu a \tau o \varsigma)$ into the wilderness vision to be tempted by the devil with regard to his divine sonship before he embarks on his ministry. While "Father" is not

22 In addition, Matthew alone describes Jesus as seeing the Spirit descent (кaì عĩ $\delta \varepsilon v$ ) before drawing the reader's attention to the heavenly voice with kai i $\delta$ ov̀. The narrative combination, usually in

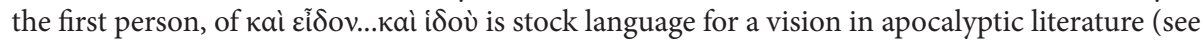
especially Rev 19:11). See chapter 3 of my PhD dissertation: (Gregory S. Thellman, "Revealing the Past and Envisioning the Future: Matthew's Apocalyptic Frame" [Ph.D. diss., Wheaton College, 2016].

23 While this arrangement is in agreement with Mark (1:12-13), Mark's account lacks the entire visionary scene as found in Matthew and Luke. Luke, however, breaks up the baptism account from the temptation account by his lengthy genealogy. Mathewson (2011) thus views both of these sections together as a unified apocalyptic vision.

24 Christopher Rowland (1982: 4, 71) defines "apocalyptic" as the unveiling of heavenly secrets. 
explicitly mentioned in the baptism, it is clearly implied by the heavenly voice that affirms Jesus as the beloved "son" in whom he is well pleased. Once again, both Jesus' divine identity and his eschatological mission are in view within a narrated revelation that incorporates God as Father, the Spirit of God and Jesus the Son. Indeed, the baptism revelation may be viewed as the model triadic passage upon which Matthew builds his triadic/dyadic pattern in the remainder of the Gospel.

\subsection{The Father and the Spirit in Jesus' First Two Teaching Discourses (5:16-7:21; 10:20)}

Repercussions of the baptism revelation are rather immediately put into effect in the narrative in the initial teaching discourse, the Sermon on the Mount (5:1-7:28), where Jesus already begins to instruct his people in the way of righteousness (5:20) and include them in the special filial relationship affirmed at his baptism by the heavenly voice. ${ }^{25}$ Throughout the Sermon on the Mount (5:17:28) Jesus refers to the "Father" seventeen times either as "in the heavens" or as the one who sees "in secret," ${ }^{26}$ language that reflects a heaven and earth dualism common in apocalyptic discourse (Pennington 2007: 231-51; 345-46). ${ }^{27} \mathrm{In}$ nearly every case "Father" is followed by the second-person personal pronoun, ${ }^{28}$ emphasizing the filial relationship disciples have with God through Jesus' mediation. ${ }^{29}$ These aspects of the discourse serve to show that through the exclusive mediation of Jesus the beloved Son (7:21-23), his disciples also have the God of the heavens as Father, recalling the affirming revelatory voice of the baptism

25 Scholars generally recognize five teaching discourses in Matthew's Gospel (5:1-7:28; 10:1-11:1; $13: 1-53 ; 18: 1-19: 1 ; 24: 1-26: 1)$ each of which conclude with a similar formulaic statement. It seems likely that Jesus' words in Matthew 28:20a rhetorically function for Matthew to point back in the narrative to these teaching sections.

26 The Father is referred to as "in the heavens" in Matthew 5:16, 45, 48; 6:1, 9, 14, 26, 32; 7:11, 21. Whenever the "Father" is not referred to as "in heaven," he is characterized as seeing "in secret" the actions of his people $(6: 4,6[2 \mathrm{x}], 18[2 \mathrm{x}])$.

27 However, the reconciliation of this cosmic dualism through the mediation of Jesus is anticipated in Matthew, most clearly in the Great Commission passage (Matt 28:18-20).

28 The exceptions are where Jesus teaches the disciples to pray (6:9), and so uses the inclusive "our Father," and in 7:21 where he refers to "my father" in his warning of eschatological judgment to those he never knew. The latter passage makes clear that only through Jesus' unique sonship can others call God "Father."

29 Robert Mowery (1997: 655; cf. 1988: 24-36) has shown that the reference to God as "Father" in Matthew only occurs in Jesus' prayers, his address to the disciples alone or to the disciples and crowds together, while "God" and "Lord" are used in other circumstances with a broader audience. 
and including them resultantly into this relationship. Moreover, these texts invite reader-listeners also into this same identification, as children of the same heavenly Father who is characterized by love, generosity and care for his people (Gathercole 2011: 64). ${ }^{30}$

This paternal relationship of God with Jesus' disciples is also shown to be mediated by the Spirit, just as in Jesus' baptism. In the second teaching discourse (10:1-11:1) Jesus commissions the disciples for mission to Israel. Here, Jesus expects persecution for the disciples on account of him, the Son, but promises that the "Spirit of your Father" ( you" ( $\dot{\varepsilon} \vee \dot{v} \mu \tilde{\imath} v)$. This promise of divine revelation by the Spirit for the disciples in effect places them, at least in an anticipatory fashion, as bearers of the messianic mission of Jesus who have access to God as Father and experience his revelatory guidance via the agency of his Spirit. ${ }^{31}$ It also provides the mode for God the Father's revelatory speech through the disciples.

\subsection{The Unity of the Father and the Son and their Reciprocal Revelatory Roles (Matt 11:25-30)}

The unity of Father and Son becomes crystallized in Matthew 11:25-30, which resembles the Great Commission (28:16-20) in its declaration of Jesus' authority. Here, Jesus prays to the Father as "Lord of heaven and earth," and yet, Jesus says all things have been handed over to him by his Father, foreshadowing the granting of "all authority in heaven and earth" in the Great Commission. This passage also references divine revelation. "These things," i.e. Jesus's teaching, have been hidden from the wise and understanding and revealed (år $\varepsilon \kappa a ́ \lambda v \psi \alpha \varsigma)$ to "little children," i.e. the disciples. Furthermore, the "Son" and the "Father" share reciprocal revelatory roles (again åmoka $\lambda \dot{\psi} \psi \alpha$ in v.27)-language that implies unity and equality, although the transmission of authority may imply a functional subordination.

While verses 25-27 are nearly an exact match with the Lukan parallel (10:21-22), Matthew's choice to include this tradition of Father-son reciprocity is nevertheless meaningful, and his placement of the text here prepares the

30 This observation does not discount the father-son metaphor in the OT. Indeed, Matthew (esp. 2:15) sees Jesus as climactically fulfilling this typology as the true Israel (Allison 1987: 74-81).

31 It is yet anticipatory, because until Jesus' resurrection, they are not called upon to teach (28:20). And, the mission to Israel as such is not recorded within the Gospel, only commissioned by Jesus. 
reader for crucial Christological-pneumatological presentation in the following chapter. ${ }^{32}$ Matthew concludes this saying with his special material, an open invitation by Jesus to the weary for rest in the style of personified wisdom of the OT (Sir.51:26-27). However, in this instance, Jesus takes on the personage of revelatory wisdom itself (see also Matt 23:34 compared to Luke 11:49), thus adding to the already revelatory flavor of the passage and portraying Jesus as "mediator of eschatological and divine revelation" (Suggs 1970: 97).

\subsection{Revealing the Spirit-Anointed Servant: The Second Fatherly Affirmation (Matt 12:18-32)}

Matthew 12 is rich in Christological claims. Jesus is here both called "one greater than the temple," recalling the earlier Emmanuel designation naming Jesus as the location of divine presence, and "Lord of the Sabbath." Then, in what is the longest OT quotation of the Gospel, Matthew cites the servant passage of Isaiah 42:1-3 (Matt 12:18-21). In this citation of prophetic speech, God draws

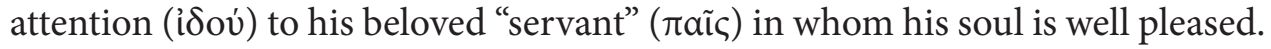
The initial words of God in this passage very closely overlap with the words of the heavenly voice at the baptism, which are in turn identical with the heavenly voice at the transfiguration. These three passages are thus tightly linked together and unified in the Isaiah citation.

\begin{tabular}{|c|c|c|}
\hline Matthew 3:17 & $\begin{array}{l}\text { Matthew 12:18a (citation of } \\
\text { Isa 42:1) }\end{array}$ & Matthew 17:5 \\
\hline 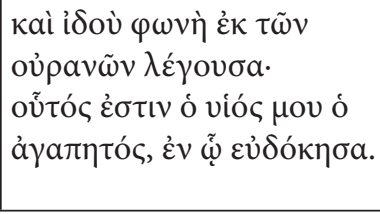 & 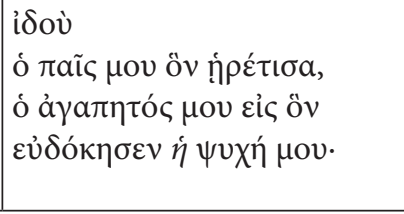 & 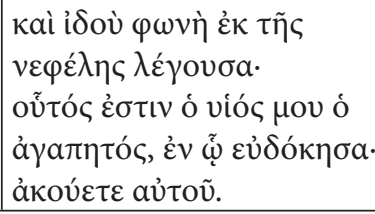 \\
\hline
\end{tabular}

Although "son" is not explicitly stated in the Isaiah quotation, the Greek raĩ often means "child," while in LXX Isaiah it translates the Hebrew for "servant" (דקֶָע). ${ }^{33}$ Indeed, the resonances with the heavenly voice both in the baptism and

32 Luke differs from Matthew only in the additional statement that Jesus "rejoiced in the Holy Spirit" (10:21). It is difficult to say here whether this is a Lukan addition or Matthean omission to their common source. In any event, the lack of reference to the Spirit in Matthew here is balanced out by the arrangement of the passage immediately before his definitive Christological-pneumatological statement in chapter 12 .

33 Luz (2001: 193) downplays the servant Christology of the passage over against the sonship Christology, but since Matthew does not follow the LXX here (except in vs. 21), it seems likely that he was aware of the Hebrew text and as such had the Isaianic דבקָ in mind too. The Greek raĩ s thus 
the transfiguration suggest Matthew hoped to highlight both the servant and son imagery here as well. The crucial descriptor ó à $\gamma a \pi \eta \tau$ ó, , found in all three passages, might be a Matthean insertion into the quotation based on the tradition of the divine voice in the baptism and transfiguration revelations (Novakovic 2003: 147). In Matthew's Isaiah citation God promised to put his Spirit upon the servant, so that readers certainly recall the Father-Son-Spirit triad in the baptism revelation. Similarly to the baptism, which Jesus enacted to fulfill all righteousness, Isaiah 42:4 emphasizes that the servant will bring about justice, but now also for the nations (vss. 18, 20).

Furthermore, there is a reference to the "name" of the servant in 12:21, the name in which the nations would hope. It is worth noting here that the Masoretic Text of Isaiah 42:3 reads that the coastlands will wait for "his Torah," but Mat-

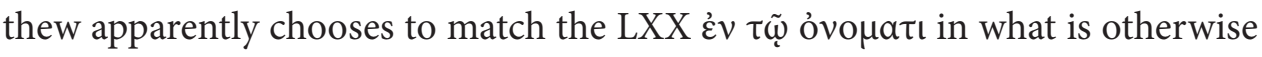
a mixed fulfillment quotation. Matthew has already explained in his comments concerning the revelation of the angel of the Lord (1:18-23), that the name Jesus indicated God's eschatological salvation for his people, and that this naming brings full meaning to the "Emmanuel" prophecy of Isaiah 7:14. Now, by citing Isaiah 42:1-4 in full, he makes clear that this name will be significant for not only Israel but the nations. The reference to the nations' hope in the name of the servant in the context of God's prophetic utterance and promise of Spirit empowerment suggests a close bond with Matthew 28:19b, where new disciples from "all nations" are baptized into the triadic name.

Matthew's choice to place the citation here amid healing and exorcism miracles of Jesus might suggest the sole aim was to be a proof text for his gentle miracle working. While this initial context may be immediately in view, many interpreters now better understand that this citation relates also to the entire section of chapters 11-13-where the break with Israel has now become evident-or even to the entire Gospel. According to Luz (2001: 192), Matthew placed the full citation here "to remind his readers of the entirety of the story of Christ." Additionally Beaton (2002: 195), after a thorough study of the text forms of Matthew's Isaianic citations, concludes:

...the extended quotation imports a distinct summary or portrait of Jesus into the narrative. The result is such that when Matthew's version is read, the quotation possesses the force of a divine pronouncement on the per- 
son of Jesus, offering not only the divine point of view but also a comprehensive description of the person of Jesus as the Spirit-endowed servant, whose mission is to compassionately establish justice for the nations.

Beaton's view that the triadic Isaiah citation has the force of a "divine pronouncement ... offering ... the divine point of view," links it even more closely with the triadic baptismal revelation (Matt 3:13-17), both as revelations of Jesus' identity and the triadic character-Father affirmed and Spirit empoweredof his messianic mission.

But, in addition, Matthew goes on in chapter 12 to offer a definitive statement of his Christological-pneumatological understanding. Immediately following the servant citation Matthew narrates Jesus' denunciation of those rejecting his ministry as those who commit blasphemy against the Spirit (12:22-32). Here in Matthew's rendition, Jesus explicitly appeals to the "Spirit of God" as the means by which he exercises power over the demonic realm ("finger of God in Luke; called "Holy Spirit" in Matt 12:32), and he then concludes that such Spirit manifested power indicates that the kingdom of God (i.e. the expected eschatological messianic age) has come into the world. That is, the Messianic mission and the works of the Messiah are enacted by means of the powerful working of the Spirit of God and cannot be understood apart from it. Indeed, this is the reason that Jesus says that the blasphemy against the Spirit alone will not be forgiven, because this kind of blasphemy is actually the rejection of God's definitive eschatological action in the world: his full presence by his Spirit in his Servant-Son. In the present context, the Pharisaic opposition to Jesus's casting out of the demon was an explicit example of this kind of blasphemy. The rejection of Jesus' Spirit empowered eschatological action was a rejection of the Holy Spirit of God.

From this point on until the end of the Gospel, the Spirit, however, will be conspicuously absent. This absence, though, in light of the crucial role of chapter 12 within the narrative, and its relation to the momentous and defining event of the baptism apocalypse, should not be understood to be a lack of concern for the Spirit on Matthew's part. Indeed, at this point of the narrative, the first evangelist has succeeded in his portrayal of Jesus as the one in whom God is fully present by his Spirit at the advent of the eschaton. The narrative of the baptism and its reiteration through the servant citation have solidified this fact in the story so that now readers know that the works of Jesus are by means of the Spirit sent by the Father. At this point on the eschatological timetable, the Spirit 
is fully active only in the Messiah. As Barrett (1947: 159) comments, "the Spirit was the possession of Jesus, as Messiah, alone, and in him it was veiled." Only after his death and resurrection will the gift of the Spirit become fully operative in the Messiah's people, and as such the Spirit will again be explicitly named in the disciple-making commission of 28:16-20.

In narrative terms, the Spirit is indeed a "character" in Matthew's Gospel. The Spirit is specifically named as the agent of the divine conception of Jesus-as an act of new creation. After descending upon Jesus at the baptism revelation, the Spirit lead Jesus into the wilderness to be tempted. Jesus promised his disciples that the Spirit would speak in or through them, in times of persecution, much as Jesus claimed that his authority over the spiritual realm was by means of the Spirit. Finally, the Holy Spirit is blasphemed. That is, according to Jesus, humans in the narrative enter into conflict with the Holy Spirit when they oppose Jesus's messianic works. ${ }^{34}$ These are indicators that Matthew has, to this point, portrayed the Spirit as an active character, rather than simply a non-personal force or power. In that sense, the Spirit does indeed for Matthew have the characteristics of personhood, but for Matthew this characterization remains essentially integrated with the one in and through whom the Spirit acts: Jesus. ${ }^{35}$

\subsection{The Revelation by the Father of the Son to Peter (Matt 16:13-28)}

The Petrine confession is often regarded as a crucial turning point of the synoptic storyline. In Matthew, Peter confesses Jesus as the Christ, the son of the living God (only "Christ" in Mark and Luke). Only in Matthew does Jesus declare that Peter's answer was based on a revelation (ả $\pi \varepsilon \kappa a ́ \lambda v \psi \varepsilon \dot{\varepsilon} v)$ to him by "my Father in the heavens" (16:16). ${ }^{36}$ Once again, Jesus is identified as the unique Son of the Father who is in the heavens, and who here reveals the truth of Jesus's identity to Peter. This is one of only three places where a human confesses the divine sonship of Jesus, and all come as responses to divine revelation or Chris-

$34 \quad$ According to William H. Shepherd, Jr. (1994: 94), "character goes with plot, and plot implies conflict." Shepherd (51-98), presents a thorough discussion of character in relation to the Holy Spirit in Luke's Gospel. Clearly, Luke appears to put more emphasis on the Spirit (both in his Gospel and in Acts), but his portrait differs from the Matthean, and this need not insinuate that Matthew necessarily thinks less of the Spirit's importance.

35 A thorough discussion of what constitutes "personhood" is well beyond the scope of this paper, although the Spirit as a "character" within the narrative can be discerned. See Schaberg (1982: 5-9) for further discussion on the Spirit as a person in Matthew.

36 Again, only in Matthew. 
tophany (Matt 14:33; 27:54). ${ }^{37}$ While the Spirit is not explicitly mentioned here, readers may recall Matthew 10:20, where the Spirit of Jesus' Father will give the disciples the words to speak when persecuted. While the present context is not one of persecution, Matthew 10:20 offers a model of how the Father enables revelatory speech by the disciples through the Spirit.

It is also at this juncture when the narrative begins to turn towards Jerusalem and a rather stunning clarification of the messianic mission. Immediately following the confession Jesus prophesizes his coming passion for the first time and is rebuked by Peter. But Peter is given the same retort as the devil during the temptation narrative and Jesus makes clear that whoever would follow him would also have to take up their cross. The messianic mission is therefore now clarified to be one that requires suffering and Jesus' disciples are called to follow him in this path. It becomes clear then that suffering too is part of the baptismal identity.

\subsection{The Revelation of the Son in the Transfiguration: The Third Fatherly Affirmation (Matt 17:1-8)}

At the transfiguration (17:1-8), and for the third time in the Gospel, the voice of the Father is heard in Matthew affirming Jesus as the beloved son. The words of the divine voice are identical to those in the baptism revelation-both drawn together by Matthew's redactions with the citation of Isa 42 in Matt 12:18-21. Once again the transfiguration is a narrated revelation and once again, like in the baptism event, Matthew intensifies the apocalyptic imagery, particularly

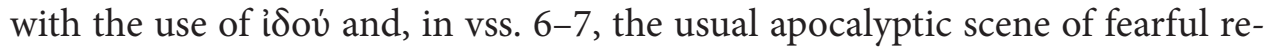
cipients and the revealer's reassurance. ${ }^{38}$ Matthew's version explicitly calls the event a "vision" (17:9). The additional message from the fatherly voice here is for the disciples to listen to Jesus. With Moses and Elijah in the vision as well, but overshadowed by Jesus, the implication is clear. The vision shows once again the divinely revealed affirmation by God of Jesus's divine sonship and authority, and now also his superiority to Israel's greatest prophets, Moses and Elijah. Further, the instruction to "listen to him" once again emphasizes the disciples' inclusion in the messianic mission.

For the revelatory context of the Centurion's confession in Matt 27:54, see Gurtner (2012: 543). For the apocalyptic character of this passage see further John R. Markley (2013).

38 For example, Dan 10:11-2; 1 En. 14:14-15:1; 2 Bar. 53:10-12; Rev 1:17. 


\subsection{God and the Spirit at the Death of Jesus (Matt 27:45-50)}

In the final moments before Jesus' death, he cries out in citation of Psalm 22:1: "my God, my God, why have you forsaken me?" (27:46). This is a surprising development in view of the narrative development earlier of Jesus' unique filial relationship to God as Father. But here, Jesus does not address God as "Father" but as "my God." While this might be the result of conformity to the source of the citation (Psalm 22) there is also the deep sense of real separation of the Father-Son relationship at this moment (Hagner 1995: 844). In addition,

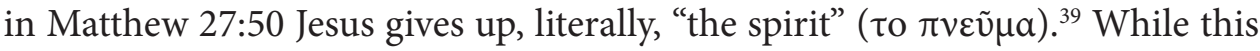
is admittedly an ambiguous passage, it must be acknowledged that $\tau$ o $\pi v \varepsilon \tilde{v} \mu \alpha$ is an unusual way to describe the release of one's life-spirit, as this passage is most often interpreted. ${ }^{40}$

However, if $\tau$ o $\pi v \varepsilon \tilde{v} \mu \alpha$ here is understood as the Spirit of God (Charette 2000: 93-94; Gurtner 2007: 140), it would reverse the revelatory events of the baptism: the forsakenness by God in place of the fatherly affirmation of Jesus' divine sonship and the release of the Spirit in place of the Spirit's descent upon him. It is perhaps then no surprise that an apocalyptic moment transpires immediately afterward. Just as the heavens were torn open at the inauguration of Jesus' Spirit empowered messianic mission, so now the temple curtain (representing the heavenlies) is torn asunder at its end (Gurtner 2007: 201; 2012: 539). ${ }^{41}$ Again, in this moment of revelation, Jesus' divine sonship is pronounced, though here not by the Father or Peter, but by the Gentile centurion and guards. However, as Gurtner argues, this confession is portrayed by Matthew as again a response to divine revelation, and thus in congruity with the only other confession of divine sonship by a human in the narrative: Peter's in Caesaria Philippi (Gurtner 2012: 543).

\footnotetext{
Typically translated "his spirit."
}

40 Indeed, Matthew's $\dot{\alpha} \varphi \tilde{\eta} \kappa \varepsilon v$ tò $\pi v \varepsilon \tilde{v} \mu \alpha$ is unique in the literature of the period. There are similar phrases, but $\psi v x \eta$ is usually employed instead of $\pi v \varepsilon \tilde{v} \mu \alpha$ (LXX Gen 35:18; 1 Esd 4:21; Eccl 12:7; Wis 16:14; T. Ab. A 17:3; L.A.E. 27:1; 45:3; 2 En. 70:16; Josephus, Ant. 1.218; 5.147; 12.430; 14.369; John 19:30).

${ }^{41} \quad$ The relinquishing of the Spirit upon death may also be seen to be the trigger for the resurrection of the holy ones (Matt 27:51-54) considering the revivification role of the Spirit in Ezekiel 37 (Charette 2000: 95-96). The tearing of the veil also reminds readers of what was attested at the Gospel's beginning: the locus of God's presence is now found in the person of the Spirit conceived Messiah. 


\subsection{Summary}

In each of the above passages, triadic or dyadic language occurs within narrated revelations or by means of apocalyptic discourse. In each case the revelatory framework affirms the divine sonship of Jesus and his messianic mission. Jesus's disciples are also included in this mission with at least initial signs of Spirit empowerment and with access to God as their Father by virtue of their association with Jesus as the unique Son who alone can reveal the Father to them. Only at the end, at the apex of the messianic mission on the cross, is the affirming voice of the Father absent and the Spirit given up, causing apocalyptic eruptions and a revelatory confession by humans of Jesus as divine son.

\section{The Restoration Command of the Resurrected Revealer}

Schaberg (1982: 26-42) rightly asserts the necessity of interpreting the triadic baptism command within the context of the pericope as a whole. Certainly, this appeal should be extended to the entire Gospel. Above I have considered key parallel texts throughout the Gospel. Below I highlight select elements of this rich passage for the purpose of contextualizing the baptism command: Jesus as divine revealer and the rhetorical inclusion of readers into the final Matthean narrative scene.

\subsection{Jesus as Divine Revealer}

When one comes to the final text of Matthew's Gospel, it is easy enough to set this pericope off from the rest of chapter 28. However, 28:16-20 must be understood within the wider narrative setting of the resurrection. In chapter 28 Matthew re-introduces the "angel of the Lord" with his apocalyptic discourse marker i $\delta o v$, who is once again presented as the divine mediator of an apocalypse (see above on 1:20-23) who discloses the transcendent reality of the resurrection of Jesus (Thellman 2016: 80-122). Then, after the angelic revelation, Jesus is introduced by a narrative i $\delta$ ov for the first time-preparing the reader for new revelatory discourse. Matthew juxtaposes Jesus' appearance to the preceding angelic revelation by the angel of the LORD in such a way that the two scenes are remarkably similar, implying that the revelatory role of the angel is now in a sense transferred to the risen Jesus. Or better, the angel of the Lord is no longer necessary as a mediating revelatory figure now that Jesus has risen. But this similarity of course contains key differences: Jesus is not described 
with sensational imagery like the angel, but he is, in contrast to the angel, worshipped. While Jesus functioned as a divine revealer earlier in the Gospel, he was also the principle object of revelation (Baynes 2017: 15-30). Now, Matthew portrays the risen Christ as the fully divine revealer who commissions his people to continue his mission by making disciples (Shaw 2007: 314).

After a likely apologetic aside that still has apocalyptic overtones (28:11-15), the disciples approach the resurrected Jesus in worship and hesitancy (standard for revelatory recipients). Jesus's claim to universal authority then establishes the basis for his sole command to make disciples of the nations, the three aspects of which are expressed by three modifying participles: going, baptizing and teaching Jesus's commands. Finally, Jesus promises his presence until the end of the age. The framing of authority and presence capture two of the major themes that define Jesus's messianic identity earlier in the Gospel, and the command to teach what Jesus has commanded clearly alludes, in a literary sense, to the five teaching discourses Matthew has compiled throughout the Gospel. These and other aspects of this concluding scene suggest that Matthew is presenting the risen Jesus with his disciples as the functioning eschatological temple. $^{42}$

Formerly, teaching was the responsibility chiefly of the temple priesthood,

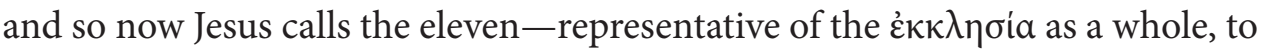
function as the teachers and scribes (cf. Matt 13:52) of eschatological Israel by reference to, what Hays calls, Jesus' "reconfigured Torah" (2005: 165-90). The final promise of presence until the "end of the age" however makes clear that the restoration commission is ongoing and valid for the $\dot{\varepsilon} \kappa \kappa \lambda \eta \sigma i \alpha$ in Matthew's time and beyond. In this sense, the commission by Jesus the revealer is "inclusive" of all Matthew's reader-listener disciples in the whole church until the end of the age. $^{43}$

42 The entire scene is based on the form of the Cyrus declaration of 2 Chronicles 36:23 (Malina 1970; Frankemölle 1974: 51-61) and against the background of that passage: the return from exile and rebuilding of the temple. In that sense, the Great Commission (Matt 28:16-20) reflects a commission to build the eschatological temple (i.e. the people of the Messiah in whom he is present) by making disciples. For this view see especially Charette (2000: 98-138) and Beale (2004: 176-77).

43 This inclusivity should not, however, be understood to mean an individual inclusivity, that is, that every individual Christian is commanded to teach and baptize, but rather a corporate, ecclesial one. The reference to the anonymous eleven implies that the passage tells us nothing about which specific members of the church are to function in these roles (i.e. the roles of pastors, clergy, etc.), only that the ecclesia-Jesus' disciples as a whole-is to do them. 


\subsection{The Narrative Theological Function of the Triadic Baptism Command}

Above I have examined Father-Son-Spirit language throughout the First Gospel. In each of these cases Jesus's identity as the beloved Son of the Father and the affirmation or authorization of his Spirit empowered messianic mission to bring about a righteous people have been expressed within narrated revelations, references to revelations, or more generally apocalyptic discourse. Furthermore, Jesus's disciples, in an anticipatory way, are granted access to God as Father through their identification with Jesus as the beloved Son and are also promised the Spirit's revelatory guidance and power as they implement their master's mission to Israel. I have noted that on the rhetorical level, Matthew's reader-listeners are also implicitly called to relate to God as Father and access Spirit empowerment through Jesus in their appropriation of these very texts.

But at the climax of the Gospel, there is now a new revelation, an ultimate apocalypse, delivered by the risen Jesus, now a heavenly, though still embodied, revealer with universal authority and worthy of full worship in his temple-the people with whom $\mathrm{He}$ is present as they go out to the nations. In his commission for the restoration of true Israel by making disciples of the nations, Jesus commands baptism in the triadic name as one of the means of this disciple-making. In light of the earlier revelations regarding Jesus and his messianic mission which involve the Father and Spirit, baptism in the triadic name seems a rather appropriate means to the goal of the empowerment of Jesus' own disciples to continue the messianic mission by commanding them through their own baptism to identify with Jesus's baptism-apocalypse as narrated in Matthew 3, and reiterated and explicated in a comprehensive fashion in Matthew 12. In this way, whenever disciples are baptized in the triadic name, it is a derivative revelatory re-enactment of Jesus' own 'triadic' baptism. Because Jesus identified with his people in their sinful state through baptism I order to bring about their righteousness, future disciples from all nations are invited to put their hope (Matt 12:18-21) in the servant-son anointed by the Father God with his Spirit by identifying with Jesus through their baptism of repentance. In this derivative way Jesus disciples too receive the anointing of the Spirit for the messianic mission in the world, and the affirmation of God their Father who is also well pleased with them as beloved children. He is now their father as well, because they are bound together with Jesus the Son, and the Spirit empowers them as well, because they follow their master in the messianic mission of justice and self-sacrificial love 
for the other, which may, as was made clear at the Petrine confession, include following the Messiah in suffering.

The triadic baptism command, as a revelation of the risen Christ, thus rhetorically functions to now fully incorporate Matthew's reader-listener disciples into the $\dot{\varepsilon} \kappa \kappa \lambda \eta \sigma i \alpha$ of the righteous ones-beneficiaries of his redeeming death and the new covenant in his blood (26:28) - so that they may continue and extend his messianic mission to the world until the end of the age. In this way, Jesus' baptism fulfills all righteousness as disciples continue to be baptized into the triadic name, and into the people of the Messiah (Matt 3:15).

\section{Conclusion}

The triadic expression is not really a "bolt from the blue," or a seemingly foreign insertion into its narrative context, neither is it a formula nor dogmatic assertion. Rather, it is a fitting narrative-theological conclusion to the series of revelations and apocalyptic discourse in Matthew's Gospel that affirm Jesus as the beloved Son in whom God his Father is fully present and through whom the Spirit of God brings the kingdom of God to bear in the world. This pattern finds its determinative point in Jesus' baptism itself (Matt 3:13-17), an apocalyptic event in which the divine, fatherly voice from the heavens affirms the sonship of Jesus and anoints him with his Spirit. It has been shown that the baptism revelation is tightly bound together with the transfiguration event (Matt 17:1-8) and the triadic servant citation in Matthew 12 (18-21), a chapter in which Matthew's Christological and pneumatological views are perhaps most acutely expressed. In addition, other passages (Matt 1:18-23; 5:1-7:28; 10:20; 11:25-27; 27:45-50) which appropriate Son, Father and sometimes Spirit language within revelations or apocalyptic discourse were shown to contribute to this developing pattern throughout the narrative.

It has also been demonstrated that the triadic baptism command itself is found within Matthew's ultimate apocalypse-the revelation of the now risen Christ to the eleven on the mountain in Galilee. Matthew presents Jesus as the now resurrected revealer with universal authority and whose divine presence is promised to his followers until the end of the age. The baptism command is therefore given within a revelation that establishes the true divine and authoritative identity of Jesus as the way in which God is fully present to his people. 
Through the triadic baptism, Jesus thus extends his Spirit empowered messianic mission begun at his own baptism though his commissioned disciples.

In light of the above evidence, I conclude that the baptism command of Matthew $28: 19 \mathrm{~b}$ is a fitting climactic conclusion to the above stated narrative-theological pattern, which then functions to invite both disciples within the narrative world and Matthew's reader-listener disciples present and future to identify fully with the Messiah in his apocalyptic baptism.

\section{Implications}

I have argued these points from a composition critical perspective based on the final form of Matthew's Gospel. Nevertheless, it is important to reflect upon the possibility of whether Jesus would likely have said something very much, or even precisely like Matthew 28:19b. Most commentators would appear here to answer in the negative, preferring to view the expression as at best representative of the thinking of the early church or the evangelist himself. However, I think it is very possible Matthew 28:19b reflects the ipsissima vox Jesu. Jesus' baptism by John is well attested across all of the Gospels and its historical basis is not seriously questioned (Wright 1996: 537). Further, it is in each Gospel presented as a powerful revelatory experience of Jesus that had a profound impact on him and others. Jesus' experience of the empowerment of the Holy Spirit, and his unique relationship to God as Father point to a triadic understanding of his identity and purpose in the world, an identity and purpose that he intended to, and in fact did, pass on to his disciples. Further, if Jesus himself experienced such a powerful baptism, it seems likely that he would command his followers to likewise be baptized as a concrete act with revelatory power, conveying not only their repentance and forgiveness of sins through him, but also their identification with him and his mission in the world. That he should then think of their baptism as also both Father-affirming and Spirit-empowering would be entirely consistent with Matthew's presentation of Jesus' teaching and experiences as shown above.

That leads to a second question for reflection; whether or not it is correct to call this passage "trinitarian." While this question deserves a much fuller discussion, this study does show that all three figures of the baptism command can be viewed as characters, that is, distinct personal agents who act within the narrative in a unified manner. Clearly, the Father is God, and the Spirit is the manifes- 
tation of God's power in the world through Jesus, but also a personal agent who initiates, leads, speaks and can be blasphemed. Finally, the narrative depiction of the resurrected Jesus in Matthew 28 as a now heavenly revealer who receives worship (already evident or anticipated earlier in the Gospel) places him explicitly alongside the Father and the Spirit.

So, at the very least the Matthean account, both in $28: 19 \mathrm{~b}$ and as a whole, sets in motion a distinctly trinitarian trajectory towards the church's eventual more developed thought. But, this study has also highlighted an aspect of the narrative that is often neglected: the distinct narrative revelatory framework of the divine actors, which, in Matthew's text, serve to draw in readers as recipients of divine revelation for the purpose of their own relating to God as Father, and as Holy Spirit, through their Lord Jesus. Consequently, Matthew's rhetorical goal in $28: 19 \mathrm{~b}$ is to draw disciples and potential disciples into a triadic or perhaps "trinitarian" confession of the fatherhood of God, the Lordship of Jesus and the empowerment of the Spirit in the concrete physical, yet spiritually revelatory act of baptism. In that sense Matthew 28:19b is at least economically "trinitarian" aimed to affirm and empower disciples of Jesus for their continued messianic mission in the world.

\section{Works Cited}

Allison, Dale C. "The Son of God as Israel: A Note on Matthean Christology." Irish Biblical Studies, vol 9, 1987, pp. 74-81.

Aus, Roger David. Matthew 1-2 and the Virginal Conception: In Light of Palestinian and Hellenistic Judaic Traditions on the Birth of Israel's First Redeemer, Moses. UPA, 2004.

Barrett, C. K. The Holy Spirit and the Gospel Tradition. SPCK, 1947.

Baynes, Leslie A. "Jesus the Revealer and the Revealed." In The Jewish Apocalyptic Tradition and the Shaping of New Testament Thought, edited by Benjamin E. Reynolds and Loren T Stuckenbruck, Fortress, 2017, pp. 15-30.

Beale, G. K. The Temple and the Church's Mission: A Biblical Theology of the Temple. NSBT 17. IVP, 2004.

Beaton, Richard. Isaiah's Christ in Matthew's Gospel. Society for New Testament Studies Monograph Series 123. Cambridge UP, 2002.

Bendoraitis, Kristian A. "Apocalypticism, Angels and Matthew." In The Jewish Apocalyptic Tradition and the Shaping of New Testament Thought, edited by Benjamin E. Reynolds and Loren T Stuckenbruck, Fortress, 2017, pp. 31-52.

Brown, Jeannine K. "Narrative Criticism." In Dictionary of Jesus and the Gospels, edited by Joel B. Green, Jeannine K. Brown and Nicholas Perrin, IVP Academic, 2013, pp. $619-24$. 
Capes, David B. “Intertextual Echoes in the Matthean Baptismal Narrative." Bulletin for Biblical Research, vol. 9, 1999, pp. 37-49.

Carey, Greg. "Introduction: Apocalyptic Discourse, Apocalyptic Rhetoric." In Vision and Persuasion: Rhetorical Dimensions of Apocalyptic Discourse, edited by Greg Carey and L. Gregory Bloomquist, 1999, pp. 1-18.

Charette, Blaine. Restoring Presence: The Spirit in Matthew's Gospel. Journal of Pentecostal Theology. Supplement Series 18. Sheffield Academic P, 2000.

Collins, John J. “Towards the Morphology of a Genre: Introduction.” Semeia, vol. 14, 1979, pp. 1-20.

Davies, W. D., and D. C. Allison. A Critical and Exegetical Commentary on the Gospel According to Saint Matthew. 3 vols. International Critical Commentary. T\&T Clark, 1988.

France, R. T. The Gospel of Matthew. New International Commentary on the New Testament. Eerdmans, 2007.

Frankemölle, Hubert. Jahwebund und Kirche Christi: Studien zur Form- und $\quad \operatorname{Tr}$ a ditionsgeschichte des Evangeliums nach Matthäus. Aschendorff, 1974.

Garland, David E. Reading Matthew: A Literary and Theological Commentary. Smyth \& Helwys, 2001.

Gathercole, Simon. “The Trinity in the Synoptic Gospels and Acts.” In The Oxford Handbook of the Trinity, edited by Gilles O.P. Emery and Matthew Levering, Oxford UP, 2011, pp. 55-68.

Gurtner, Daniel M. "Interpreting Apocalyptic Symbolism in the Gospel of Matthew." Bulletin for Biblical Research, vol. 22, 2012, pp. 525-45.

---. The Torn Veil: Matthew's Exposition of the Death of Jesus. Society for New Testament Studies Monograph Series 139. Cambridge UP, 2007.

Hagner, Donald A. Matthew 14-28. WBC 33b. Word, 1995.

Hays, Richard B. “The Gospel of Matthew: Reconfigured Torah.” Hervormde teologiese studies, vol. 61, 2005, pp. 165-90.

Kingsbury, Jack Dean. “Composition and Christology of Matt 28:16-20.” Journal of Biblical Literature, vol. 93, 1974, pp. 573-84.

---. Matthew as Story. 2nd ed. Fortress, 1988.

Luz, Ulrich. Matthew 8-20: A Commentary. Augsburg Fortress Publishers, 2001.

---. Matthew 21-28: A Commentary. Augsburg Fortress Publishers, 2005.

Malina, Bruce J. "Literary Structure and Form of Matt 28:16-20.” New Testament Studies, vol. 17, 1970, pp. 87-103.

Markley, John R. Peter - Apocalyptic Seer: The Influence of the Apocalypse Genre on Matthew's Portrayal of Peter. Wissentschaftliche Untersuchungen zum Neuen Testament 2/348. Mohr Siebeck, 2013.

Mathewson, David. “The Apocalyptic Vision of Jesus According to the Gospel of Matthew: Reading Matthew 3:16-4:11 Intertextually." Tyndale Bulletin, vol. 62, 2011, pp. 89108. 
Mowery, Robert L. "From Lord to Father in Matthew 1-7." Catholic Biblical Quarterly, vol. 59, 1997, pp. 642-56.

---. “God, Lord and Father: The Theology of the Gospel of Matthew." Biblical Research, vol. 33, 1988, pp. 24-36.

Novakovic, Lidija. Messiah, the Healer of the Sick: A Study of Jesus as the Son of David in the Gospel of Matthew. Wissentschaftliche Untersuchungen zum Neuen Testament 2/170. Mohr Siebeck, 2003.

Pennington, Jonathan T. Heaven and Earth in the Gospel of Matthew. Supplements to Novum Testamentum, 126. Brill, 2007.

Powell, Mark. Methods for Matthew. Cambridge UP, 2009.

Rhoads, David. "Narrative Criticism." In Characterization in the Gospels, edited by David Rhoads and Kari Syreeni, Journal for the Study of the New Testament Supplement Series 184, Sheffield Academic Press, 1999, pp. 264-85.

Rowland, Christopher. The Open Heaven: A Study of Apocalyptic in Judaism and Early Christianity. Crossroad, 1982.

Schaberg, Jane. The Father, the Son and the Holy Spirit: The Triadic Phrase in Matthew 28:19b. Society of Biblical Literature, 1982.

Shaw, Frances. Discernment of Revelation in the Gospel of Matthew. Religions and Discourse 30. Peter Lang, 2007.

Shepherd, Jr., William H. The Narrative Function of the Holy Spirit as a Character in LukeActs. Society of Biblical Literature Dissertation Series 147. Scholars P, 1994.

Suggs, M. Jack. Wisdom, Christology, and Law in Matthew's Gospel. Harvard UP, 1970.

Thellman, Gregory S. "Revealing the Past and Envisioning the Future: Matthew's Apocalyptic Frame." Ph.D. diss., Wheaton College, 2016.

Thiselton, Anthony C. The Holy Spirit: In Biblical Teaching, Through the Centuries, and Today. Eerdmans, 2013.

Wright, N. T. Jesus and the Victory of God. SPCK, 1996. 


\section{NARATIVNO-TEOLOŠKA FUNKCIJA U MATEJEVU IZVJEŠTAJU O ZAPOVIJEDI KRŠTENJA (Mt 28,19b)}

\begin{tabular}{c} 
Sažetak \\
\hline Gregory S. THELLMAN \\
Visoko evanđeosko teološko učilište \\
Cvjetkova 32 \\
HR - 31 000 Osijek \\
greg.thellman@evtos.hr
\end{tabular}

Zapovijed krštenja u ime Presvetog Trojstva u Matejevu evanđelju (Mt 28,19) često se smatra nezgodnim u tom kontekstu te možebitno anakronističkim u svjetlu kasnije kršćanske trinitarne doktrine. U radu se tvrdi da je Mt 28,19 prilično prikladan, klimaktičan zaključak narativno-teološkog motiva koji prožima Matejevo evanđelje, u kojem se trojstvene ili barem dijadne formule koriste $\mathrm{u}$ kontekstima objave koji potvrđuju Isusovo božansko sinovstvo i mesijansku misiju: ili u malim apokalipsama ili unutar apokaliptičnog diskursa. Srž toga argumenta nalazi se u samome Isusovu krštenju (3,13-17), koje se predstavlja kao apokalipsa u kojoj božanski Očev glas otkriva Sinov identitet i pomazuje ga svojim Duhom, s izrečenim ciljem da „ispun[i] svu pravednost“. Objavu donosi Matej i to tako da je upućena publici u narativu te implicitno čitatelju, odnosno učeniku. Objava krštenja potom se usko povezuje s poduljim citatom Izaije (42,1-4) kod Mt 12, 18-21, još jednim tekstom o Trojstvu i preobraženju (17,1-8). I drugi se odlomci analiziraju radi utvrđivanja obrasca u čitavome Evanđelju. U narativu o uskrsnuću (28,1-20) pokazano je da je uskrsnuli Isus sada božanski, ali još uvijek utjelovljen objavitelj s božanskom vlašću (čašću) tako da se odlomak o sveopćem poslanju (njegovih učenika) (28,16-20) prikazuje kao božanska objava. Unutar te „krajnje apokalipse" uskrsnuli Isus zapovijeda svojim sljedbenicima da od naroda stvaraju učenike naukom i krštenjem u ime Trojstva. Zapovijed krštenja, u svjetlu motiva Trojstva $\mathrm{u}$ čitavom evanđelju, ima retorički učinak pozivanjem Matejevih čitatelja - slušatelja da se poistovjećuju s Isusom u njegovu krštenju, tako da i oni imaju uspostavljeni sinovski odnos s Bogom i primaju pomazanje Duha Svetoga da nastave širiti Isusovu mesijansku misiju u svijetu, vođeni njegovim univerzalnim autoritetom i obećanom prisutnošću.

Ključne riječi: Isus, Matejevo evanđelje, Otac, Duh Sveti, krštenje, objava, apokaliptično, Trojstvo 